\title{
Foreign Direct Investment, Regulations, and Growth
}

\author{
Matthias Busse ${ }^{\mathrm{a} *}$ and José Luis Groizard ${ }^{\mathrm{b}}$
}

\begin{abstract}
The paper explores the linkage between income growth rates and foreign direct investment (FDI) inflows. So far the evidence is rather mixed, as no robust relationship between FDI and income growth has been established. We argue that countries need a sound business environment in the form of good government regulations to be able to benefit from FDI. Using a comprehensive data set for regulations, we test this hypothesis and find evidence that excessive regulations restrict growth through FDI only in the most regulated economies. This result holds true for different specifications of the econometric model, including instrumental variable regressions.
\end{abstract}

JEL Classification: C31, F21, F43, L51

Key Words: $\quad$ Multinationals, Spillovers, Institutions, Development

World Bank Policy Research Working Paper 3882, April 2006

The Policy Research Working Paper Series disseminates the findings of work in progress to encourage the exchange of ideas about development issues. An objective of the series is to get the findings out quickly, even if the presentations are less than fully polished. The papers carry the names of the authors and should be cited accordingly. The findings, interpretations, and conclusions expressed in this paper are entirely those of the authors. They do not necessarily represent the view of the World Bank, its Executive Directors, or the countries they represent. Policy Research Working Papers are available online at http://econ.worldbank.org.

\footnotetext{
${ }^{\mathrm{a}}$ Hamburg Institute of International Economics (HWWA), Neuer Jungfernstieg 21, 20347 Hamburg, Germany; bUniversitat de les Illes Balears, Department of Applied Economics, Ctra. de Valldemossa Km. 7.5, 07122 Palma de Mallorca, Spain; *Author for correspondence: e-mail busse@hwwa.de, phone +49-40-42834-435, fax +4940-42834-451. The paper was partly written while the first author was visiting the World Bank Development Economics Research Group International Trade. The authors would like to thank Teodosio Pérez Amaral, Caroline Freund, Beata Javorcik, Mariana Spatareanu, and participants at seminars at the World Bank, Goettingen, Muenster, Vigo, and at conferences in Lübeck ( $8{ }^{\text {th }}$ Annual GTAP Conference) and Dublin ( $7^{\text {th }}$ Annual ETSG Conference) for helpful discussions and comments on an earlier draft. Lars Vogel and Wendy Soh provided excellent research assistance.
} 


\section{Introduction}

The enormous increase in foreign direct investment (FDI) flows across countries is one of the clearest signs of the globalization of the world economy over the past 20 years. Total FDI flows increased from some US \$55 billion in 1985 to US \$1,511 billion before falling back to US \$573 billion in 2003 (World Bank 2005a). Even as a share of gross domestic product (GDP), we do observe an enormous increase in the significance of FDI. In high-income countries, this share increased from some 0.5 to 1.0 percent in the 1980 s to more than 5 percent in 2000 and then declined to 1.4 percent in 2003 (Figure 1). While the increase in FDI inflows was less drastic in low- and middle-income countries, the percentage of FDI in GDP remained at more than 2 percent after the year 2000, indicating a slightly higher significance of FDI flows in developing countries in the most recent period.

Figure 1: Foreign Direct Investment Inflows as a Share of GDP, 1970-2003

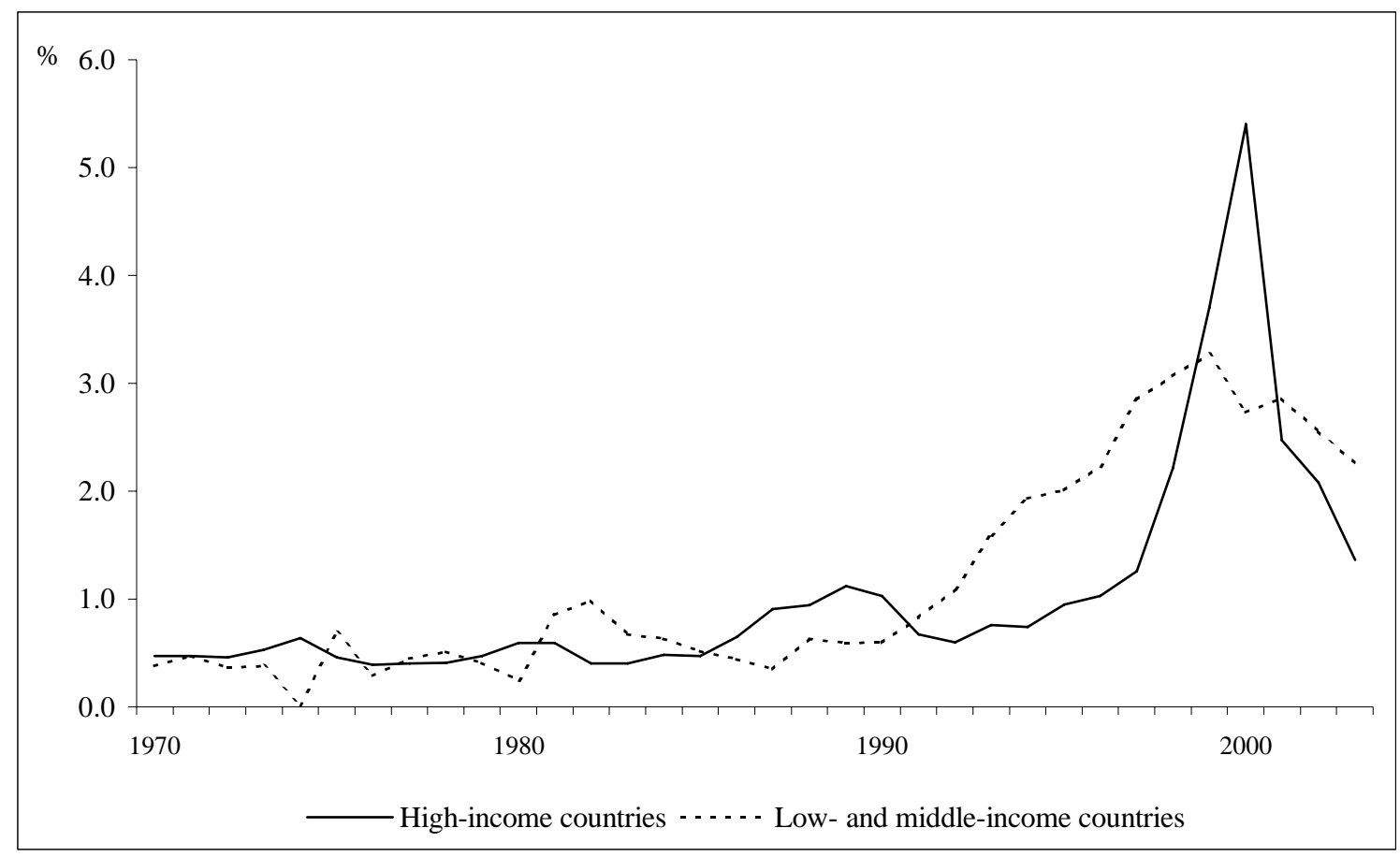

Source: World Bank (2005a).

Over the last couple of decades, the theoretical literature on the impact of foreign investment flows on host economies has identified several channels for FDI to influence per capita income growth rates. As a start, FDI may provide new capital, allowing additional investment in both human and physical capital, which can be very beneficial for (developing) countries 
with liquidity constraints. ${ }^{1}$ In contrast to short-term capital flows, long-term foreign investment is much more likely to be valuable to host economies, in particular if the investment takes the form of new or expanding production plants.

Moreover, foreign investment inflows are generally accepted as a means to incorporate new knowledge from abroad. The theory of the multinational firm proposes that multinational corporations have a technological advantage over local firms that outweighs the cost of doing business in external markets (Caves 1996, Markusen 2002). The inflow of new knowledge may benefit domestic firms through imitation and learning (Findlay 1978, Mansfield and Romeo 1980, Blomström 1986), increasing competition in local markets, facilitating human capital mobility among firms (Fosfuri et al. 2001, Glass and Saggi 2002) and vertical linkages (Rodríguez-Clare 1996, Markusen and Venables 1999), thereby increasing the productivity level and sustaining a higher growth rate.

Despite the fact that the economic benefits of increasing FDI inflows are well established in the theoretical literature, the evidence on technology spillovers is far from conclusive in both firm-level and country-level data. ${ }^{2}$ For example, Aitken and Harrison (1999) could not establish any evidence of a positive technology spillover from multinationals to domestic firms in Venezuela in the 1980s. On the other hand, Görg and Hijzen (2004) find that imitation and learning can take place when local firms are geographically close to multinationals and have enough absorptive capacity. Using firm-level data for Lithuania, Javorcik (2004) discovers that spillovers may occur through backward linkages between multinationals and their local suppliers. Another finding is that labor turnover might act as an important channel. As multinationals train the workforce in their operations abroad to use new technologies, technology diffusion might also occur due to a labor turnover from multinationals to domestic firms or if locals establish their own business (Djankov and Hoekman 2000).

Unlike most of the microeconomic evidence, studies using aggregated FDI data found questionable support that FDI in itself significantly boosts growth rates in all recipient

\footnotetext{
${ }^{1}$ Much of the earlier literature has emphasised differences in capital abundance and returns on capital as the main driving force for capital flows across countries. See Caves (1996) for a literature survey.

${ }^{2}$ De Mello (1997) and Li and Liu (2005) provide surveys of the literature. See also Görg and Greenaway (2004) for a review of the empirical literature on multinationals and productivity spillovers.
} 
countries. In a cross-sectional regression framework, Ram and Zhang (2002) find some evidence that FDI is boosting host economies' income growth rates, based on data for the 1990s. Yet they note that the results are not robust to all their model specifications. UNCTAD (1999), on the other hand, fails to find a clear linkage between FDI and growth rates, as the sign of the coefficient for FDI is either positive or negative depending on the variables that enter the regressions. In a similar approach, Dutt (1997) also falls short of detecting any empirical linkage between foreign investment and per capita growth rates.

Nonetheless, using a panel of data for the 1970-1999 period for 84 countries, Li and Liu (2005) establish a clear linkage between FDI and growth rates. They confirm this outcome for different econometric techniques, including a simultaneous equation system. In contrast, Carkovic and Levine (2005) also use a panel setting and control for simultaneity bias, but do not find robust results for positive growth effects of FDI inflows in their sample of 72 countries for the 1960-1995 period. They note that this outcome (and the inconclusive evidence in the literature in general) might be due to the specific empirical approaches and the different time periods used.

Apart from data and methodological issues, a few studies have tried to find further reasons for the inconclusive evidence. Based on their results, Balasubramanyam et al. (1996) note that FDI might promote growth only in export-promoting rather than in import-substituting countries and that, thus, openness to trade is essential for the growth effects of foreign investment. Borensztein et al. (1998) find that certain characteristics in the host countries may play an important role. More specifically, they discover that countries need a particular educational attainment level to benefit from FDI. Borensztein et al. argue that to be able to benefit from positive (technological) spillover effects, host economies have to have the educational capacity to incorporate these effects.

More recently, two papers have been published that examined the linkages between the effectiveness and regulations of financial markets, FDI and growth. In essence, Hermes and Lensink (2003) and Alfaro et al. (2004) find that countries with better financial systems and financial market regulations can exploit FDI more efficiently and achieve a higher growth rate. Both studies argue that countries need not only a sound banking system, but also a functioning financial market to allow entrepreneurs to obtain credit to start a new business or 
expand an existing one. In this way, countries are able to benefit from inward investment to achieve a higher growth rate.

Aside from financial market regulations, the impact of broader government regulations on the interaction between FDI and growth has not been analyzed so far. Our paper intends to fill this gap, as we explore the linkages between government regulations, FDI and economic growth in a comprehensive manner. It can be argued that countries may only benefit from foreign investment inflows if they have appropriate local government regulations and institutions in place. Excessive regulations are likely to restrict growth through FDI if human and capital resources are prevented from reallocation. For example, if starting and closing down a business are hindered by extensive and costly government regulations, involving many bureaucratic procedures demanding entrepreneurs' time and resources, capital flows are prevented from being reallocated to the most productive sectors.

Likewise, if restrictive employment laws for hiring and firing of employees cause a lower labor market turnover, technology spillovers to domestic firms are less likely to occur. A similar argument can be made for other forms of government regulations, such as protecting (foreign and domestic) investors by ensuring creditor rights and enforcement of contracts. Both are difficult tasks involving high uncertainty, considerable time and very large expenses. Hence, multinationals would reduce forward and backward linkages with the local economy, thereby affecting the likelihood of horizontal or vertical spillovers taking place. In summary, restrictive government regulations may prevent productivity increases related to the exploitation of technology spillovers from foreign direct investment inflows.

Against this backdrop, we will use a broad range of government regulations, employing the extensive Doing Business database on government regulations provided by the World Bank (2004), and test our hypothesis that countries with restrictive regulations cannot exploit FDI inflows efficiently. The World Bank database has the main advantage of focusing on relatively consistent and objective data in measuring regulations across countries. More explicitly, the effects of starting and closing down a business, labor market regulations, enforcing contracts, creditor rights and obtaining credit are examined. These forms of regulations are likely to affect the reallocation of resources and, consequently, the positive effects of FDI inflows in an economy. 
Overall, we find that FDI does not stimulate growth in economies with excessive business and labor regulations, after controlling for some other relevant determinants of observed changes in GDP growth rates. However, this outcome is restricted to the top 20 or 30 percent most regulated countries, indicating that there is a threshold level for which our results do hold up. This outcome has some powerful policy implications, as governments have first to improve the regulatory quality in their countries to be able to benefit from increased openness to foreign capital in the form of direct investment.

The paper is structured as follows: The next section describes the regulation data used, whereas Section 3 presents the specification of the econometric model. We use standard OLS regression analysis and, since a number of the independent variables are likely to be endogenous, an instrumental variable approach. The results will be presented in Section 4 and finally, Section 5 summarizes the main results and concludes with some policy implications.

\section{Measuring Regulations}

For a long time, researchers who examined the impact of institutions and regulations across countries had to rely on a few sources, such as the indicators on political risk provided by the PRS Group (2005) in their International Country Risk Guide or the government effectiveness indicators from the annual Global Competitiveness Report supplied by the World Economic Forum (2005). These organizations publish a large variety of relevant indicators, for instance, on the level of corruption or the quality of the bureaucracy, which are clearly relevant for the effects of institutions and government regulations. These indicators, however, are derived from the results of executive opinion surveys and thus presents the perceived level of corruption or the rule of law. Predominantly, they do not use factual information to measure differences in institutions and regulations across countries.

Recently, the World Bank started to publish results from their Doing Business project (World Bank 2004). The Doing Business database provides objective measures of business regulations and their enforcement. The Doing Business indicators are comparable across economies and indicate the regulatory costs of business. They allow us to obtain information on regulatory outcomes, such as time and money spent on bureaucratic procedures, and thus to investigate the efficiency of the government institutions in place. By focusing on evidence 
for regulations, we obtain more objective indicators that are less influenced by stages of economic development or recent events. ${ }^{3}$ These indicators, in turn, can then be used to analyze specific regulations that enhance or constrain investment, productivity and growth.

Out of seven indicators in the database, we have chosen those that are clearly applicable to test the linkages between the inflow of foreign investment and economic growth in the host economy. That leaves us with five sub-components, namely, starting a business, labor market regulations, contract regulations, creditor rights and insolvency regulations. The starting-abusiness indicator is the (arithmetic) mean of the average number of procedures to start a business, the number of days and the costs required to complete that process, ${ }^{4}$ while the labor market regulation index is an average of three indexes: flexibility of hiring, conditions of employment and flexibility of firing. The contract regulation index is an average of three indexes covering the number of judicial procedures to enforce a contract, the duration and the cost, whereas the creditor rights index measures four powers of secured creditors in bankruptcy. Finally, for the insolvency index we use the goals of insolvency index from the Doing Business dataset that reflect the difficulties in closing down a business.

To get an overall index of regulations we compute a weighted average of the five individual components of regulations, taking factor loadings in principal components analysis as weights. ${ }^{5}$ Higher values for all five sub-components (and, thus, for the aggregated regulation index) reflect more regulations, that is, regulations with a lower quality for business operations. While the Doing Business indicators are available for a total of 145 countries, we had to restrict our sample to 89 countries. Included in the following analysis are all countries for which data on regulations, the dependent and all independent variables are available. ${ }^{6}$ Base year for the regulation index is January 2003. For our country sample, the combined indicator ranges from -4.24 to -0.42 , with a mean of -2.1 and a standard deviation of 0.85 .

\footnotetext{
${ }^{3}$ For an extended discussion of the advantages of the Doing Business indicators, see World Bank (2004). In general, the Doing Business database is widely recognised (and used) as a high-quality measure of regulations across countries. For instance, Bolaky and Freund (2004) and Pica and Mora (2005) have used the Doing Business indicators in their empirical work.

${ }^{4}$ Before taking the average for this indicator, all three sub-components are rescaled to 0-1 by dividing all observations by the highest figure in each of the three sub-components.

${ }^{5}$ Before combining the five regulation indicators, we have taken the logarithm of each of them. This procedure yields negative values for the regulation index for all countries.

${ }^{6}$ See Appendix $\mathrm{C}$ for the country sample.
} 
Similar to the quality of institutions, it has been pointed out in numerous studies that regulatory quality is an important determinant of overall income levels. ${ }^{7}$ It is therefore not surprising that the regulation index is strongly (negatively) correlated with income per capita levels (Table 1). Similarly, the regulation indicator is also negatively associated with GDP per capita growth rates in the period 1994 to 2003, the most recent 10-year period, indicating that stricter regulations are associated with lower GDP growth rates, though the correlation coefficient is much smaller in comparison to GDP per capita. The regulation index is also negatively correlated with FDI inflows in that period, with a coefficient of a similar size $(-0.34)$ in comparison to GDP growth rates.

Table 1: Correlation Matrix

\begin{tabular}{lcccc}
\hline Variable & $\begin{array}{c}\text { Regulation } \\
\text { index, } \\
2003\end{array}$ & $\begin{array}{c}\text { In GDP per capita, } \\
\text { PPP \$, } \\
2003\end{array}$ & $\begin{array}{c}\text { GDP per capita } \\
\text { growth rate, } \\
1^{1994-2003}{ }^{1}\end{array}$ & $\begin{array}{c}\text { FDI inflows, } \\
\text { \% of GDP, } \\
1994-2003^{1}\end{array}$ \\
\hline $\begin{array}{l}\text { Regulation index, 2003 } \\
\text { In GDP per capita, PPP \$, }\end{array}$ & -0.66 & 1.00 & \\
2003 & -0.33 & 0.32 & 1.00 & \\
$\begin{array}{l}\text { GDP per capita growth } \\
\text { rate, 1994-2003 }\end{array}$ & & & 0.32 & 1.00 \\
$\begin{array}{l}\text { FDI inflows, \% of GDP, } \\
\text { 1994-2003 }\end{array}$ & -0.34 & 0.27 & & \\
\hline
\end{tabular}

Note: ${ }^{1}$ Annual average.

In our country sample, FDI inflows are somewhat closely associated with GDP growth rates, as the correlation coefficient is in the medium range (0.32). This outcome is supported by the partial scatter plot of both variables, shown in Figure 2, which includes a fitted regression line. Yet a correlation, simple regression or a graph cannot establish a linkage between the variables, since we have other determinants of economic growth to take into account. We will do so in the following sections.

\footnotetext{
${ }^{7}$ See, for example, Acemoglu et al. (2001), Dollar and Kraay (2002) and Rodrik et al. (2004).
} 
Figure 2: FDI Inflows and GDP Growth Rates, 1994-2003

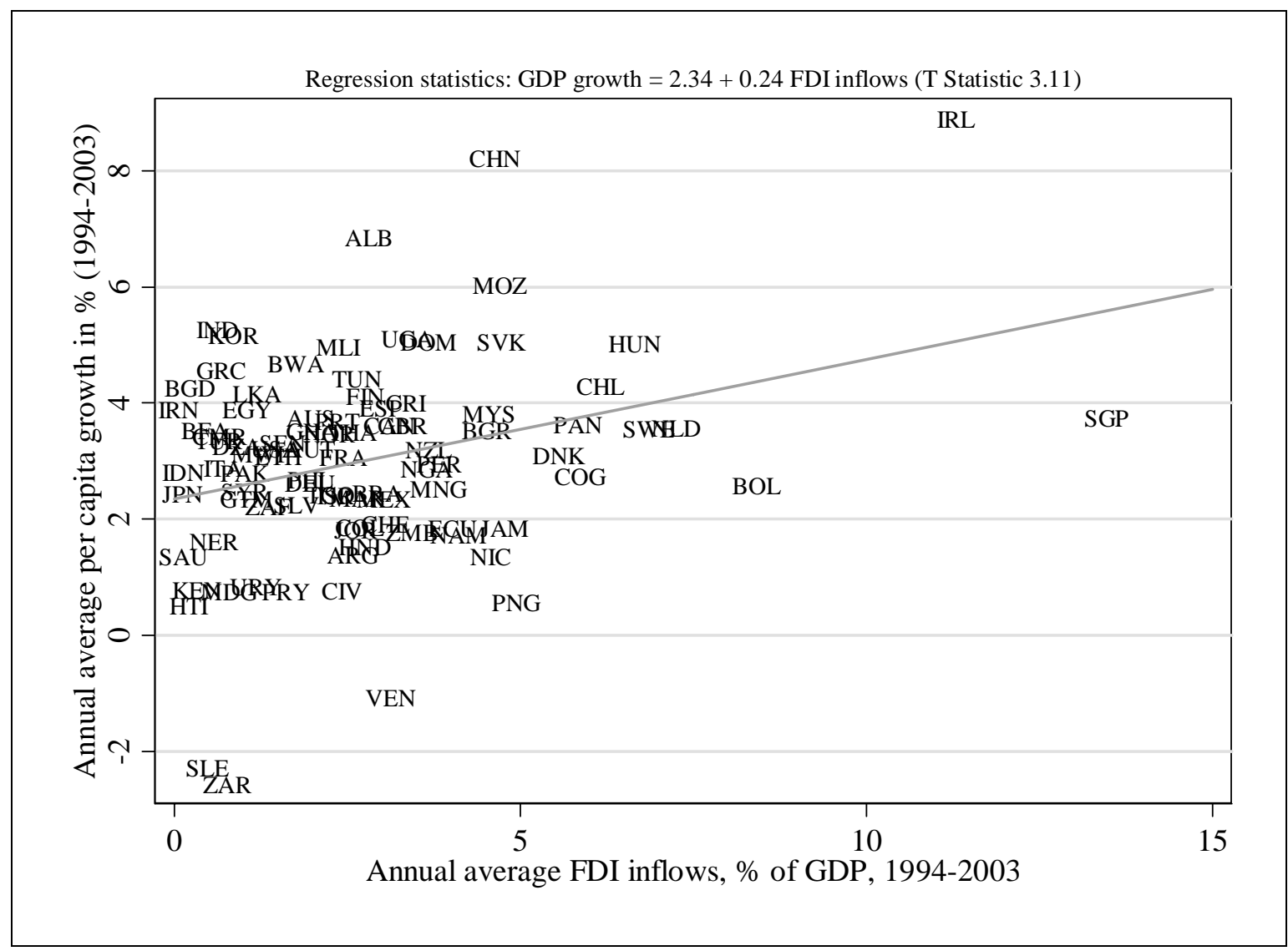

\section{Model Specification}

To analyze the interaction of foreign investment, regulations and growth, we could use the "standard" cross-country growth regression model that usually is specified as follows:

$$
y_{i t}-y_{i t-1}=\theta y_{i t-1}+\gamma^{\prime} X_{i t}+e_{i t} \text {, }
$$

where $y$ is the $\log$ of per capita GDP for country $\mathrm{i}$ and periods $\mathrm{t}$ and $\mathrm{t}-1, X$ are a set of explanatory variables, including regulations, FDI inflows and other control variables, $\theta$ and $\gamma$ are the coefficients to be estimated for the initial GDP per capita $y_{t-1}$ and the control variables, respectively, and $e$ is the error term. By following this approach, however, we are likely to obtain biased estimates due to the well-known problems of cross-country growth regression, such as reverse causality, measurement errors, omitted variables or simultaneity. 
To deal with these issues, a panel data approach including changes over time in the variables in question would be preferable. Unfortunately, our regulations indicator is limited to information in 2003 only, which does allow us to explore changes in a dynamic setting. ${ }^{8}$ Nevertheless, since changes in government regulations are relatively slow, it is reasonable to assume that our regulation index is roughly constant over a limited period of time, for instance, the last 10 years. Based on this assumption, we can analyze changes in the other key variables, that is, FDI flows, GDP growth rates and the control variables, over time in dynamic regressions. In effect, we follow the approach of Caselli, Esquivel and Lefort (1996) and Dollar and Kraay (2002) and transform (1) by taking into account that there are country effects $\eta_{i}$ included in the error term that are likely to be correlated to the explanatory variables producing biased coefficients in a pure OLS estimation. Thus, the model can be rewritten as:

$$
y_{i t}=\alpha y_{i t-1}+\gamma^{\prime} X_{i t}+\eta_{i}+\varepsilon_{i t},
$$

where $\alpha$ is $1+\theta$.

To avoid the country effect bias we estimate (2) in differences:

$$
y_{i t}-y_{i t-1}=\alpha\left(y_{i t-1}-y_{i t-2}\right)+\gamma^{\prime}\left(X_{i t}-X_{i t-1}\right)+\left(\varepsilon_{i t}-\varepsilon_{i t-1}\right) \text {. }
$$

In essence, we regress growth in the most recent period of 10 years, that is, 1994-2003, on growth in the previous period (1984-1993) and on changes from the previous to the current period in FDI and the other explanatory variables. ${ }^{9}$ As the independent variables, we always use FDI inflows, measured as annual average of net FDI inflows as a share of GDP, and an indicator for the rule of law. The latter indicator measures various components of the institutional quality of a country that might not be captured by our regulation index, such as the incidence of crime or the effectiveness and predictability of the judiciary. Overall, countries with well-designed institutions are less likely to have bad regulations.

\footnotetext{
${ }^{8}$ The World Bank’s Doing Business dataset will be updated and extended every year, which will allow panel data analysis in the future.

${ }^{9}$ In the following, the period 1994-2003 will be referred as the current period, whereas 1984-1993 is the previous period.
} 
In addition, we include a measure for the quality of regulations. We do not, however, include the regulation index, as all constant explanatory variables are eliminated when we take first differences. Instead, we construct an interactive term with FDI to ensure that regulations are properly included. Importantly, regarding the intensity of regulations it could be expected that regulations hinder countries from taking advantage of higher FDI inflows, but this might apply only to countries with relatively restrictive regulations. To check this hypothesis, we split the sample of countries using a threshold for the top 20 percent most regulated economies. ${ }^{10}$ More specifically, using the regulation index we construct a dummy variable (Regulation Dummy) that takes the value 1 for the top 20 percent most regulated economies and zero otherwise. We then compute an interactive term of the regulation dummy and FDI to see whether regulations in the most regulated countries matter and add that to the list of independent variables. ${ }^{11}$ Additionally, we follow the literature and add the following control variables: ${ }^{12}$

- black market premium for foreign currency (US dollar) in percent

- changes in consumer prices in percent

- population growth in percent

- government consumption, calculated as total government consumption as a share of GDP

- openness to trade, computed as imports and exports divided by GDP

To control for regional characteristics in explaining variations in GDP growth rates across countries, we also add a set of regional dummies, namely, Sub-Saharan Africa, Asia, Middle East \& North Africa, Latin America \& the Caribbean, Europe and North America.

It can be argued that all of the independent variables are in fact endogenous. Lagged growth and the error term in (3) are correlated by construction. Therefore, we should exploit the moment conditions in a dynamic panel setting to find the adequate instrument. Additionally, FDI may not only lead to higher growth rates, but growing markets might attract multinational corporations. The growth (and size) of a particular market is likely to be an

\footnotetext{
${ }^{10}$ We later change the threshold to test the robustness of our results.

${ }^{11}$ We tried to interact the regulation index directly with FDI; the sign was as expected but the significance was lower than in our final approach.

${ }^{12}$ These explanatory variables have been used, for instance, by Borensztein et al. (1998), Alfaro et al. (2004) and Carkovic and Levine (2005). Data sources for all variables are provided in Appendix A, while Appendix B shows descriptive statistics.
} 
indication of its level of attractiveness to the investment, in the case that the multinational corporation aims to produce for the local market (horizontal or market-seeking FDI), thereby boosting growth rates of the host country (Chakrabarti 2001, Busse 2004).

In effect, we rely on the identifying assumption that the $X$ explanatory variables are weakly exogenous. Hence, FDI and regulations may be correlated with the contemporaneous and lagged shocks of GDP growth but they are uncorrelated with future shocks of GDP growth. As has been pointed out by Carkovic and Levine (2005), weak exogeneity does not mean that multinationals do not consider expected future growth in their decision to undertake FDI. It rather means that unexpected future shocks do not influence current FDI.

To deal with the problem of endogeneity, we use the two stages least squares (2SLS) estimator. As appropriate instruments, we employ the log-level of the GDP per capita at the beginning of the period $y_{i t-2}$ to instrument for lagged growth. To instrument for changes in FDI and in the interacted term, we use FDI levels and the interaction of FDI and the regulation dummy variable at the beginning of the period $\mathrm{t}-1$. When the explanatory variables do not show significant variation over time, lagged variables in levels make weak instruments for the regression in differences, and we need to include lagged differences in explanatory variables as additional instruments. We therefore add to the list of instruments the change over previous periods in FDI. Above all, starting with the contribution by Wheeler and Moody (1992), strong evidence has emerged in the literature to suggest that past FDI flows are in effect a powerful determinant of present or future investment decisions by multinational corporations. ${ }^{13}$ Multinationals are much more likely to be attracted by countries that already have considerable FDI inflows. Firms' own experiences in host countries and the success of other multinationals serve as a strong attraction for further foreign investments.

We extend our list of instruments by adding a set of variables that has been developed in the cross-country growth literature based on history and geography: legal origin (British and French), distance from equator and a dummy for landlocked countries. ${ }^{14}$ Hall and Jones (1999) interpret that distance from equator might act as a proxy of western influence. There is

\footnotetext{
${ }^{13}$ See also the empirical studies by Borensztein et al. (1998), Gastanaga et al. (1998) and Jensen (2003), who all find that a lagged FDI variable has a highly significant coefficient in their regressions, even though they use very different specifications.
} 
evidence that the legal origin is still a major determinant of the current institutional setting and regulatory quality of a country (La Porta et al. 1998, 1999). ${ }^{15}$ Along these lines, Acemoglu et al. (2001) find that mortality rates of European settlers a couple of hundred years ago still are a highly significant determinant of the present institutional quality in a country and use this variable as an instrument. Unfortunately, using settler mortality would severely reduce the number of countries included in the regressions, which could bias the results. As a consequence, we do not use settler mortality rates but rather concentrate on the legal origin and the geographical variables.

\section{Empirical Results}

We start the empirical analysis with ordinary least squares (OLS). While this method is inconsistent and is likely to lead to biased estimates, as pointed out earlier, it is useful to summarize the partial correlations in the data. To explain growth in the current period, we start with a simple benchmark regression, reported in column 1 of Table 2, including only changes in average FDI and average rule of law as well as growth in the previous time period. The coefficients for FDI and previous growth are highly significant at the 1 percent level and both have positive signs. Changes in the rule of law do have a positive impact on growth, but the estimated coefficient is not significant. In contrast to some of the studies surveyed in the first section, the sign of the coefficient for FDI means that changes in average foreign investment inflows have a positive impact on growth. The estimated coefficient means that an increase in the ratio of FDI inflows to GDP from the previous to the current period by 1 percentage point is associated with an increase in the annual average GDP per capita growth rate in the current period of 0.28 , which is quite a significant impact.

The positive linkage between FDI and growth does not change if we add the interactive term of changes in FDI inflows and the regulation dummy for the 20 percent most regulated countries and a set of other control variables or regional dummies (columns 2 to 9). Yet this outcome has to be seen in perspective of the time period (and econometric model) chosen.

\footnotetext{
${ }^{14}$ We also exploit the interactions of the legal origin with the instruments selected from our identifying assumptions.

${ }^{15}$ Likewise, Djankov et al. (2002) find that French legal origin is highly correlated with an excessive regulatory environment.
} 
Since we analyze averages for the current period 1994-2003 and changes from the previous to the current period, we focus on a period of very high FDI flows (Figure 1) that may drive our results. Nevertheless, our results support the findings by Li and Liu (2005), who find a positive linkage between FDI and growth, which in particular holds true for the 1990s in their data sample.

If we add the interactive term of changes in FDI and the regulation dummy, we obtain a negative coefficient that is significant at the 5 percent level (column 2). Importantly, the coefficient for the interactive term is about the same size as the one for changes in FDI. For the 20 percent most regulated countries this outcome implies that the net impact of foreign investment inflows is close to zero, as an increase in our FDI variable by 1 percentage point is associated with a very small decrease in the per capita growth rates of -0.01 percentage points $(+0.35-0.36)$. When we add further control variables (columns 3 to 7$)$, both the sign and size of the coefficient for the interactive term do not change much. Even though the significance level slightly decreases, we still get relatively robust results for the interactive term. Also, the coefficients for FDI and the interactive term are roughly similar. ${ }^{16}$ The interactive term, however, is no longer significant if we include the set of regional dummies, mainly because variations in growth rates are to a considerable degree associated with regional characteristics. When we include all five additional explanatory variables at the same time, the size and significance level of the interactive term declines as well. Yet with a p-value of 0.119 , the coefficient just fails to reach the 10 percent level. Overall, the results provide first evidence for the hypothesis that the most regulated countries cannot take advantage of changes in FDI inflows.

\footnotetext{
${ }^{16}$ We test the joint significance of FDI with the interaction term, using an appropriate $F$ test. The hypothesis that both coefficients are jointly zero cannot be rejected at the 1 or 5 cent level, depending on the specification of the model (see Table 2).
} 
Table 2: FDI and Growth, Top 20 Percent Most Regulated Countries (OLS)

\begin{tabular}{|c|c|c|c|c|c|c|c|c|c|}
\hline \multirow[b]{2}{*}{ Independent Variables } & \multicolumn{9}{|c|}{ Dependent Variable: Growth in current period } \\
\hline & $(1)$ & $(2)$ & (3) & $(4)$ & $(5)$ & $(6)$ & $(7)$ & $(8)$ & $(9)$ \\
\hline Constant & $\begin{array}{c}1.25 * * \\
(2.48)\end{array}$ & $\begin{array}{c}1.37 * * * \\
(2.84)\end{array}$ & $\begin{array}{c}1.31 * * * \\
(2.61)\end{array}$ & $\begin{array}{c}1.22 * * * \\
(2.78)\end{array}$ & $\begin{array}{c}1.43^{* * *} \\
(2.81)\end{array}$ & $\begin{array}{c}0.90 * * \\
(2.06)\end{array}$ & $\begin{array}{l}1.12 * * \\
(2.28)\end{array}$ & $\begin{array}{c}1.26 * * \\
(2.34)\end{array}$ & $\begin{array}{c}0.84^{*} \\
(1.71)\end{array}$ \\
\hline Change over previous period in average FDI & $\begin{array}{c}0.28 * * * \\
(2.92)\end{array}$ & $\begin{array}{c}0.35^{* * *} \\
(3.86)\end{array}$ & $\begin{array}{c}0.33^{* * *} \\
(3.58)\end{array}$ & $\begin{array}{c}0.36^{* * *} \\
(3.67)\end{array}$ & $\begin{array}{c}0.35^{* * *} \\
(3.95)\end{array}$ & $\begin{array}{c}0.30 * * * \\
(3.20)\end{array}$ & $\begin{array}{c}0.33^{* * *} \\
(4.00)\end{array}$ & $\begin{array}{c}0.26 * * * \\
(2.55)\end{array}$ & $\begin{array}{c}0.31^{* * *} \\
(3.65)\end{array}$ \\
\hline Change over previous period in average & & $-0.36^{* *}$ & $-0.32 *$ & $-0.35 * *$ & $-0.38 * *$ & $-0.26^{*}$ & $-0.31 * *$ & -0.17 & -0.23 \\
\hline FDI*Regulation Dummy & & $(-2.08)$ & $(-1.74)$ & $(-2.02)$ & $(-2.07)$ & $(-1.71)$ & $(-1.95)$ & $(-1.09)$ & $(-1.58)$ \\
\hline Growth in previous period & $\begin{array}{c}0.33^{* * *} \\
(3.44)\end{array}$ & $\begin{array}{c}0.31 * * * \\
(3.21)\end{array}$ & $\begin{array}{c}0.32 * * * \\
(3.20)\end{array}$ & $\begin{array}{c}0.32 * * * \\
(3.60)\end{array}$ & $\begin{array}{c}0.29 * * * \\
(2.82)\end{array}$ & $\begin{array}{c}0.40 * * * \\
(4.41)\end{array}$ & $\begin{array}{c}0.28 * * * \\
(3.07)\end{array}$ & $\begin{array}{c}0.36 * * * \\
(3.95)\end{array}$ & $\begin{array}{c}0.35^{* * *} \\
(3.62)\end{array}$ \\
\hline Change over previous period in average rule of law & $\begin{array}{c}0.23 \\
(1.42)\end{array}$ & $\begin{array}{c}0.21 \\
(1.41)\end{array}$ & $\begin{array}{c}0.27 \\
(1.60)\end{array}$ & $\begin{array}{c}0.20 \\
(1.29)\end{array}$ & $\begin{array}{c}0.22 \\
(1.48)\end{array}$ & $\begin{array}{c}0.36^{* *} \\
(2.46)\end{array}$ & $\begin{array}{c}0.20 \\
(1.35)\end{array}$ & $\begin{array}{c}0.37 * * \\
(2.29)\end{array}$ & $\begin{array}{c}0.37 * * \\
(2.43)\end{array}$ \\
\hline Change over previous period in average inflation rate & & & $\begin{array}{c}0.10 \\
(0.29)\end{array}$ & & & & & & $\begin{array}{c}0.39 \\
(1.12)\end{array}$ \\
\hline $\begin{array}{l}\text { Change over previous period in average population } \\
\text { growth }\end{array}$ & & & & $\begin{array}{l}-0.26 \\
(-0.54)\end{array}$ & & & & & $\begin{array}{c}0.20 \\
(0.55)\end{array}$ \\
\hline $\begin{array}{l}\text { Change over previous period in average government } \\
\text { consumption }\end{array}$ & & & & & $\begin{array}{c}0.03 \\
(0.59)\end{array}$ & & & & $\begin{array}{c}0.03 \\
(0.40)\end{array}$ \\
\hline Change over previous period in average BMP & & & & & & $\begin{array}{l}-0.05 \\
(-0.15)\end{array}$ & & & $\begin{array}{l}-0.19 \\
(-0.52)\end{array}$ \\
\hline Change over previous period in average trade & & & & & & & $\begin{array}{c}1.92 * * * \\
(2.75)\end{array}$ & & $\begin{array}{l}1.41^{*} \\
(1.73)\end{array}$ \\
\hline Regional dummies $^{1}$ & No & No & No & No & No & No & No & Yes & No \\
\hline $\begin{array}{l}\text { F-value for joint test on change over previous period } \\
\text { in average FDI and change over previous period in } \\
\text { average FDI*Regulation Dummy }\end{array}$ & & $7.64 * * *$ & $6.78^{* * *}$ & $6.80^{* * *}$ & $7.94 * * *$ & $5.16^{* * *}$ & $8.17^{* * *}$ & $3.28 * *$ & $6.87 * * *$ \\
\hline $\mathrm{R}^{2}$ & 0.29 & 0.34 & 0.35 & 0.34 & 0.34 & 0.43 & 0.38 & 0.47 & 0.48 \\
\hline Observations & 89 & 89 & 88 & 89 & 89 & 82 & 89 & 89 & 82 \\
\hline
\end{tabular}


Table 3: FDI and Growth, Top 20 Percent Most Regulated Countries (2SLS)

\begin{tabular}{|c|c|c|c|c|c|c|c|c|c|}
\hline \multirow[b]{2}{*}{ Independent Variables } & \multicolumn{9}{|c|}{ Dependent Variable: Growth in current period } \\
\hline & $(1)$ & $(2)$ & (3) & (4) & (5) & (6) & $(7)$ & $(8)$ & $(9)$ \\
\hline Constant & $\begin{array}{c}-0.07 \\
(-0.14)\end{array}$ & $\begin{array}{c}0.39 \\
(0.80)\end{array}$ & $\begin{array}{c}0.47 \\
(1.00)\end{array}$ & $\begin{array}{c}0.49 \\
(0.88)\end{array}$ & $\begin{array}{c}0.43 \\
(0.84)\end{array}$ & $\begin{array}{c}0.37 \\
(0.77)\end{array}$ & $\begin{array}{c}0.27 \\
(0.57)\end{array}$ & $\begin{array}{c}0.40 \\
(0.64)\end{array}$ & $\begin{array}{c}0.45 \\
(0.85)\end{array}$ \\
\hline Change over previous period in average FDI & $\begin{array}{c}0.32 * * \\
(2.19)\end{array}$ & $\begin{array}{c}0.43 * * * \\
(2.86)\end{array}$ & $\begin{array}{c}0.48 * * * \\
(3.02)\end{array}$ & $\begin{array}{c}0.42 * * * \\
(2.75)\end{array}$ & $\begin{array}{c}0.41 * * * \\
(2.73)\end{array}$ & $\begin{array}{c}0.41 * * * \\
(2.85)\end{array}$ & $\begin{array}{c}0.44 * * * \\
(3.05)\end{array}$ & $\begin{array}{c}0.42 * * * \\
(2.90)\end{array}$ & $\begin{array}{c}0.45^{* * *} \\
(3.02)\end{array}$ \\
\hline Change over previous period in average & & $-0.50 * *$ & $-0.50 * *$ & $-0.52 * *$ & $-0.49 * *$ & $-0.46^{* *}$ & $-0.47 * *$ & $-0.48 * *$ & $-0.48 * *$ \\
\hline FDI*Regulation Dummy & & $(-2.36)$ & $(-2.37)$ & $(-2.44)$ & $(-2.27)$ & $(-2.11)$ & $(-2.28)$ & $(-2.32)$ & $(-2.20)$ \\
\hline Growth in previous period & $\begin{array}{c}0.54 * * * \\
(4.99)\end{array}$ & $\begin{array}{c}0.43^{* * *} \\
(3.67)\end{array}$ & $\begin{array}{c}0.38 * * * \\
(3.08)\end{array}$ & $\begin{array}{c}0.42 * * * \\
(3.48)\end{array}$ & $\begin{array}{c}0.43 * * * \\
(3.40)\end{array}$ & $\begin{array}{c}0.45^{* * *} \\
(4.15)\end{array}$ & $\begin{array}{c}0.40 * * * \\
(3.46)\end{array}$ & $\begin{array}{c}0.47 * * * \\
(3.73)\end{array}$ & $\begin{array}{c}0.40 * * * \\
(3.56)\end{array}$ \\
\hline Change over previous period in average rule of law & $\begin{array}{c}0.77^{* *} \\
(2.35)\end{array}$ & $\begin{array}{c}0.73^{* *} \\
(2.26)\end{array}$ & $\begin{array}{c}0.82 * * * \\
(2.49)\end{array}$ & $\begin{array}{c}0.75^{* *} \\
(2.28)\end{array}$ & $\begin{array}{c}0.75^{* *} \\
(2.27)\end{array}$ & $\begin{array}{c}0.72 * * * \\
(2.65)\end{array}$ & $\begin{array}{c}0.68 * * \\
(2.18)\end{array}$ & $\begin{array}{c}0.43 \\
(1.11)\end{array}$ & $\begin{array}{c}0.71^{* * *} \\
(2.65)\end{array}$ \\
\hline Change over previous period in average inflation rate & & & $\begin{array}{c}0.44 \\
(1.27)\end{array}$ & & & & & & $\begin{array}{c}0.51 \\
(1.47)\end{array}$ \\
\hline $\begin{array}{l}\text { Change over previous period in average population } \\
\text { growth }\end{array}$ & & & & $\begin{array}{c}0.19 \\
(0.47)\end{array}$ & & & & & $\begin{array}{c}0.18 \\
(0.43)\end{array}$ \\
\hline $\begin{array}{l}\text { Change over previous period in average government } \\
\text { consumption }\end{array}$ & & & & & $\begin{array}{c}0.04 \\
(0.80)\end{array}$ & & & & $\begin{array}{c}0.05 \\
(0.91)\end{array}$ \\
\hline Change over previous period in average BMP & & & & & & $\begin{array}{c}0.02 \\
(0.06)\end{array}$ & & & $\begin{array}{l}-0.25 \\
(-0.78)\end{array}$ \\
\hline Change over previous period in average trade & & & & & & & $\begin{array}{l}1.28 * \\
(1.67)\end{array}$ & & $\begin{array}{c}0.77 \\
(0.92)\end{array}$ \\
\hline $\begin{array}{l}\text { Regional dummies }^{1} \\
\text { Shea partial } \mathrm{R}^{2} \text { (first-stage) }\end{array}$ & No & No & No & No & No & No & No & Yes & No \\
\hline Change over previous period in average FDI & 0.31 & 0.32 & 0.31 & 0.34 & 0.32 & 0.39 & 0.33 & 0.38 & 0.39 \\
\hline $\begin{array}{l}\text { Change over previous period in average } \\
\text { FDI*Regulation Dummy }\end{array}$ & & 0.47 & 0.50 & 0.46 & 0.46 & 0.48 & 0.47 & 0.47 & 0.50 \\
\hline Growth in previous period & 0.41 & 0.36 & 0.32 & 0.35 & 0.33 & 0.44 & 0.35 & 0.40 & 0.42 \\
\hline Change over previous period in average rule of law & 0.21 & 0.21 & 0.22 & 0.21 & 0.20 & 0.35 & 0.21 & 0.16 & 0.36 \\
\hline $\begin{array}{l}\text { Hansen-Sargan overidentification test } \\
\left(\chi^{2} \text { p-value }\right)\end{array}$ & $\begin{array}{c}18.8 \\
(0.22)\end{array}$ & $\begin{array}{l}14.1 \\
(0.44)\end{array}$ & $\begin{array}{c}12.8 \\
(0.55)\end{array}$ & $\begin{array}{c}13.9 \\
(0.45)\end{array}$ & $\begin{array}{c}15.3 \\
(0.36)\end{array}$ & $\begin{array}{c}13.9 \\
(0.46)\end{array}$ & $\begin{array}{c}13.6 \\
(0.48)\end{array}$ & $\begin{array}{l}17.2 \\
(0.25)\end{array}$ & $\begin{array}{c}14.4 \\
(0.42)\end{array}$ \\
\hline $\mathrm{R}^{2}$ & 0.31 & 0.34 & 0.33 & 0.34 & 0.35 & 0.35 & 0.38 & 0.45 & 0.40 \\
\hline Observations & 86 & 86 & 86 & 86 & 86 & 82 & 86 & 86 & 82 \\
\hline
\end{tabular}

Instrumented variables: Change over previous period in average FDI, change over previous period in average FDI*Regulation Dummy (except in column 1), growth in previous period, and change over previous period in average rule of law. Instruments: Distance to equator, dummy landlocked country, log of GDP per capita in 1984, FDI in 1984, average FDI in the previous period, rule of law in 1984, dummies for British and French law, interactive terms between legal dummies and FDI, legal dummies and regulation dummy, and included exogenous variables. 
The results of the instrumental variable (IV) regressions for the top 20 percent most regulated countries are reported in Table 3. Similar to the first OLS regression, we start with changes in FDI but not the interactive term. As can be seen from column 1, an increase in FDI inflows is still associated with a rise in growth rates. Furthermore, this result holds even if other control variables are added (columns 2 to 9). We thus conclude that an increase in FDI inflows contributes to GDP per capita growth in our data sample. Likewise, growth in the previous period and changes in the rule of law also contribute to explaining variations in growth rates, as not only the coefficient for previous growth but also the one for changes in the rule of law is positive and highly significant.

The interaction of the FDI variable with the regulation dummy continues to have a negative coefficient in all eight different specifications. In all specifications, the coefficient is significantly different from zero, even if we include regional dummies (column 8) or all additional explanatory variables at the same time (column 9). In contrast to the OLS regressions, the size of the coefficient for the interactive term is larger than the one for FDI in all eight specifications, which strengthens the results that the most regulated countries would not observe any positive growth effects from FDI inflows. Based on our results, the opposite outcome can be expected.

We assess the validity of the instruments using the Hansen-Sargan test for overidentifying restrictions. Our IV regressions are based on the assumption that the instruments are uncorrelated with the error term in the growth equation. The results for the p-value of the $J$-test for each IV specification are reported in Table 3. We cannot reject the null hypothesis that the instruments are uncorrelated with the error term in all eight specifications for the FDI variable, the interactive term and previous growth rates. This result means that our instruments are affecting growth but only through the FDI variable, the interaction of the FDI and regulation index variables and changes in the growth rate. For changes in the rule of law, the results are somewhat weaker, as the p-values are beyond conventional levels (that is, above 0.10), indicating that our instruments are not entirely convincing for this variable. Yet we have run further regressions, treating the rule of law variable as exogenous or adding further instruments. While this approach might solve the problem with the rule of law variable, we do not get any changes in sign or significance levels for both the FDI and the interactive term, which further underlines the robustness of our results. 
Another important issue with IV estimation is to test for the instrument relevance. Since we are using more instruments than endogenous variables we do not know if the instruments collectively capture the independent variation in the right-hand-side variables. One way to assess this issue is to take a closer look at the magnitude of the $\mathrm{R}^{2}$ in the first stage for each endogenous variable. The Shea first stage $\mathrm{R}^{2}$ shows that the partial $\mathrm{R}^{2}$ for changes in average FDI is between 30 and 40 percent in all eight model specifications, which is reasonable. For the interactive term, the figures are even better, as the Shea first stage $\mathrm{R}^{2}$ is in the range of 0.45 to 0.50 , indicating a relatively good fit. For the other two explanatory variables, all Shea's partial $\mathrm{R}^{2}$ are above 10 percent, which means that all instruments are relevant in Shea's sense and thus, the instruments have sufficient relevance for the right-hand side variables in the growth regression.

In another set of regressions, we repeat the exercise for the top 30, 40 and 50 percent most regulated economies. These further tests are useful to ascertain whether the results are influenced by the particular threshold level chosen for the regulation dummy. In comparison to the top 20 percent most regulated countries, the significance levels of the coefficient for the interactive term are somewhat weaker but roughly similar if we set the cut-off point at the top 30 percent most regulated economies (Table 4). The interactive term is also statistically significant in six out of eight OLS regressions, but only in four out of eight IV regressions. Yet the number of significant coefficients declines considerably if we increase the threshold level to top 40 or 50 percent most regulated countries. These results mean that there is a particular threshold level, which is highly relevant for our results. In other words: Low quality regulations do not allow the top 20 or 30 percent most regulated economies to take advantage of FDI inflows. 
Table 4: OLS and IV Results Using Different Threshold Levels for the Regulation Dummy

\begin{tabular}{|c|c|c|c|}
\hline \multirow[b]{2}{*}{$\begin{array}{l}\text { Percentage of most regulated } \\
\text { countries for the cut-off point } \\
\text { of the regulation dummy }\end{array}$} & \multicolumn{3}{|c|}{$\begin{array}{l}\text { Number of regressions where interactive term FDI*Regulation Dummy is } \\
\text { significant }{ }^{1}\end{array}$} \\
\hline & $\begin{array}{c}\text { OLS } \\
\text { (8 regressions) }\end{array}$ & $\begin{array}{c}\text { IV (2SLS) } \\
\text { (8 regressions) }\end{array}$ & $\begin{array}{c}\text { Total } \\
\text { (16 regressions) }\end{array}$ \\
\hline Top 20 percent & $6 / 8$ (6 out of 8$)$ & $8 / 8$ (8 out of 8$)$ & $14 / 16$ (14 out of 16$)$ \\
\hline Top 30 percent & $6 / 8$ & $4 / 8$ & $10 / 16$ \\
\hline Top 40 percent & $4 / 8$ & $0 / 8$ & $4 / 16$ \\
\hline Top 50 percent & $0 / 8$ & $0 / 8$ & $0 / 16$ \\
\hline
\end{tabular}

Note: ${ }^{1} 10$ percent significance level or better. The interactive term always has a negative sign.

So far, we have used the aggregated regulation index for the computation of the regulation dummy. In a further set of regressions, we identify those regulation sub-components that drive our results by applying them individually. Out of the five sub-components, starting-abusiness shows the strongest results if we focus on the top 20 percent most regulated countries. In comparison to the aggregated regulation index, the significance levels for the new interactive term, where the dummy is based on regulations on starting a business only, are even slightly higher: For 15 out of 16 OLS and IV regressions, we obtain a negative and significant coefficient for the interactive term (Table 5$).{ }^{17}$ For this sub-component, the outcome is very similar if we select a higher threshold level for the dummy, as significance levels of the interactive term drop considerably for the top 30, 40 or 50 percent most regulated countries.

Table 5: OLS and IV Results Using Sub-components for Regulations

\begin{tabular}{ccccc}
\hline $\begin{array}{c}\text { Percentage of most regulated } \\
\begin{array}{c}\text { countries for the cut-off point } \\
\text { of the regulation dummy }\end{array}\end{array}$ & $\begin{array}{c}\text { Number of regressions where interactive term FDI*Regulation Dummy is } \\
\text { negative and significant out of a total of 16 regressions (8 OLS and } 8 \text { IV) }\end{array}$ \\
\hline Top 20 percent & $15 / 16$ & $\begin{array}{c}\text { Labor market } \\
\text { regulations }\end{array}$ & $\begin{array}{c}\text { Closing a } \\
\text { business }\end{array}$ & $\begin{array}{c}\text { Contract } \\
\text { enforcement }\end{array}$ \\
Top 30 percent & $9 / 16$ & $6 / 16$ & $0 / 16$ & $0 / 16$ \\
Top 40 percent & $0 / 16$ & $13 / 16$ & $0 / 16$ & $13 / 16$ \\
Top 50 percent & $0 / 16$ & $7 / 16$ & $0 / 16$ & $3 / 16$
\end{tabular}

Note: ${ }^{1} 10$ percent significance level or better.

\footnotetext{
${ }^{17}$ Detailed results for all sub-components are not shown due to space constraints. Like all other results, they are available upon request.
} 
For the labor market regulation index and contract enforcement, we obtain slightly different results. For both sub-components, the coefficients for the new interactive terms reach their highest significance levels when we use the top 30 or 40 percent most regulated countries rather than the lower threshold level. Hence, we observe different cut-off points regarding the impact of regulations on growth rates via the interaction with FDI. But even for these indicators, we see a clear decline in the number of significant coefficients as we move to the top 50 percent cut-off point.

On the other hand, closing down a business does not affect growth rates via FDI flows, since the interactive term fails to reach at least the conventional 10 percent significance level in any regression and threshold level. ${ }^{18}$ If we exclude this sub-component, the results for our aggregated indicator become even stronger, but still show declining significance levels as we increase the percentage for the cut-off point. In general, these results underline the fact that some individual regulations, such as starting a business, the rigidity of employment and enforcing a contract, matter more for the interaction of FDI, regulations and growth. Nevertheless, we think that the overall level of regulations in a country, which affects the reallocation of factor endowments, has several important contributing components that are difficult to disentangle and we believe that the overall level of regulations matters most.

Finally, we have run several further robustness checks to test the explanatory power of our fundamental hypothesis that the most regulated countries are not likely to take advantage of FDI inflows. For this exercise, we have used a different econometric model, that is, we run level regressions using the log of GDP per capita and FDI stocks (as a percentage of GDP) to analyze the long-term impact of FDI inflows on income levels. ${ }^{19}$ Importantly for the robustness of our results, the sign and significance level of the interactive term do not change much. However, we obtain slightly different results for cut-off points for the top 20 and 30 percent most regulated countries. ${ }^{20}$ While this underlines our basic result, it also indicates that the number of countries (based on our sample) that are less likely to benefit from an increase in FDI inflows fluctuates between these two figures.

\footnotetext{
${ }^{18}$ We have excluded the fifth sub-component, getting credit, as there are only five different values for all countries. In comparison to the other four sub-components, we cannot establish the same clear cut-off points.

${ }^{19}$ Results are not shown due to space constraints.

${ }^{20}$ For example, focussing on the top 30 per cent most regulated countries yields stronger results than those for the top 20 per cent. Yet we also observe declining significance levels of the interactive term as we increase the cut-off point above 30 per cent.
} 


\section{Concluding Remarks}

In comparison to less regulated countries, our results indicate that more regulated economies are less able to take advantage of the presence of multinational companies. This result is further evidence of the fact that important host country characteristics can lead to a positive impact of foreign investment inflows on growth rates. While Borensztein et al. (1998) have singled out educational attainment levels and Hermes and Lensink (2003) and Alfaro et al. (2004) the importance of financial markets, our empirical results support the view that regulations are another fundamental determinant of the beneficial effects of FDI reaped in host economies.

All these results have important policy implications. However, our results do not provide evidence that regulations across all countries (included in our sample) matter, but rather, that they restrict growth through foreign investment inflows only in the most regulated economies. Any attempts by government to attract capital in the form of foreign direct investment by offering special tax breaks are not likely to yield the expected beneficial effects if the regulatory quality is rather low. In addition to increasing educational attainment levels and boosting the regulatory quality and liquidity of financial markets, host countries have to reform their fundamental framework for regulations to enhance chances that FDI inflows can contribute to higher growth rates. Thus, our research results are basically in line with those stressing the need for an adequate institutional framework, in order for trade liberalization and economic integration to be successful. According to the findings of some recent studies (Dollar and Kraay 2002, Rodrik et al. 2004, and Bolaky and Freund 2004), international trade stimulates growth only in economies with better institutions and less excessive business and labor regulations. Our results lead us to conclude that regulations affect the interaction of FDI and growth rates in a very similar way. To achieve positive welfare effects of FDI inflows, governments first have to tackle the institutional setting and regulatory framework in their countries. 


\section{References}

Acemoglu, Daron, Simon Johnson and James Robinson (2001), The Colonial Origin of Comparative Development: An Empirical Investigation, American Economic Review, Vol. 91, No. 5, pp. 1369-1401.

Aitken, Brian and Ann Harrison (1999), Do Domestic Firms Benefit from Direct Foreign Investment? Evidence from Venezuela, American Economic Review, Vol. 89, No. 3, pp. 605-618.

Alfaro, Laura, Areendam Chanda, Sebnem Kalemli-Ozcan and Selin Sayek (2004), FDI and Economic Growth: The Role of Local Financial Markets, Journal of International Economics, Vol. 64, No. 1, pp. 89-112.

Balasubramanyam, Vudayagiri, Mohammed Salisu and David Sapsford (1996), Foreign Direct Investment and Growth in EP and IS Countries, Economic Journal, Vol. 106, No. 434, pp. 92-105.

Blomström, Magnus (1986), Foreign Investment and Productive Efficiency: The Case of Mexico, Journal of Industrial Economics, Vol. 35, No. 1, pp. 97-110.

Bolaky, Bineswaree and Caroline Freund (2004), Trade, Regulations, and Growth, World Bank Policy Research Paper 3255.

Borensztein, Eduardo, José De Gregorio, Jong-wha Lee (1998), How Does Foreign Direct Investment Affect Economic Growth?, Journal of International Economics, Vol. 45, No. 1, pp. 115-135.

Busse, Matthias (2004), Transnational Corporations and Repression of Political Rights and Civil Liberties: An Empirical Analysis, Kyklos, Vol. 57, No. 1, pp. 45-66.

Carkovic, Maria and Ross Levine (2005), Does Foreign Direct Investment Accelerate Economic Growth?, in Theodore Moran, Edward Graham and Magnus Blomström (eds.), Does Foreign Direct Investment Promote Development?, Washington, DC: Institute for International Economics, pp. 195-220.

Caselli, Francesco, Gerardo Esquivel and Fernando Lefort (1996), Reopening the Convergence Debate: A New Look at Cross-country Growth Empirics, Journal of Economic Growth, Vol. 1, No. 3, pp. 363-389.

Caves, Richard (1996), Multinational Enterprises and Economic Analysis, Second Edition, Cambridge, UK: Cambridge University Press.

Chakrabarti, Avik (2001), The Determinants of Foreign Direct Investment: Sensitivity Analyzes of Cross-Country Regressions, Kyklos, Vol. 54, No. 1, pp. 89-113.

De Mello, Luiz Reis (1997), Foreign Direct Investment in Developing Countries and Growth: A Selective Survey, Journal of Development Studies, Vol. 34, No. 1, pp. 1-34.

Djankov, Simeon, Rafael La Porta, Florencio López-de-Silanes and Andrei Shleifer (2002), The Regulation of Entry, Quarterly Journal of Economics, Vol. 117, No. 1, pp. 1-37.

Djankov, Simeon and Bernard Hoekman (2000), Foreign Investment and Productivity Growth in Czech Enterprises, World Bank Economic Review, Vol. 14, No. 1, pp. 49-64.

Dollar, David and Aart Kraay (2002), Institutions, Trade, and Growth, Journal of Monetary Economics, Vol. 50, No. 1, pp. 133-162. 
Dutt, Amitava Krishna (1997), The Pattern of Direct Foreign Investment and Economic Growth, World Development, Vol. 25, No. 11, pp. 1925-1936.

Findlay, Ronald (1978), Relative Backwardness, Direct Foreign Investment and the Transfer of Technology: A Simple Dynamic Model, Quarterly Journal of Economics, Vol. 62, No. 1, pp. 1-16.

Fosfuri, Andrea, Massimo Motta and Thomas Ronde (2001), Foreign Direct Investment and Spillovers Through Workers' Mobility, Journal of International Economics, Vol. 53, No. 1, pp. 205-222.

Gastanaga, Victor; Jeffrey Nugent and Bistra Pashamova (1998), Host Country Reforms and FDI Inflows: How Much Difference Do They Make?, World Development, Vol. 26, No. 7, pp. 1299-1314.

Glass, Amy Jocelyn and Kamal Saggi (2002), Multinational Firms and Technology Transfer, Scandinavian Journal of Economics, Vol. 104, No. 4, pp. 495-513.

Görg, Holger and David Greenaway (2004), Much Ado About Nothing? Do Domestic Firms Really Benefit from Foreign Direct Investment?, World Bank Research Observer, Vol. 19, No. 2, pp. 171-197.

Görg, Holger and Alexander Hijzen (2004), Multinationals and Productivity Spillovers, GEP Research Paper 2004/41, University of Nottingham.

Hall, Robert and Charles Jones (1999), Why Do Some Countries Produce So Much More Output per Worker than Others?, Quarterly Journal of Economics, Vol. 114, No. 1, pp. 83-116.

Hermes, Niels and Robert Lensink (2003), Foreign Direct Investment, Financial Development and Economic Growth, Journal of Development Studies, Vol. 40, No. 1, pp. 142-163.

Javorcik, Beata (2004), Does Foreign Direct Investment Increase the Productivity of Domestic Firms? In Search of Spillovers Through Backward Linkages, American Economic Review, Vol. 94, No. 3, pp. 605-627.

Jensen, Nathan (2003), Democratic Governance and Multinational Corporations: Political Regimes and Inflows of Foreign Direct Investment, International Organization, Vol. 57, No. 3, pp. 587-616.

La Porta, Rafael, Florencio Lopez-de-Silanes, Andrei Shleifer and Robert Vishny (1998), Law and Finance, Journal of Political Economy, Vol. 106, No. 6, pp. 1113-1155.

La Porta, Rafael, Florencio Lopez-de-Silanes, Andrei Shleifer and Robert Vishny (1999), The Quality of Government, Journal of Law, Economics, and Organization, Vol. 15, No. 1, pp. 222-279.

Li, Xiaoying and Xiaming Liu (2005), Foreign Direct Investment and Economic Growth: An Increasingly Endogenous Relationship, World Development, Vol. 33, No. 3, pp. 393-407.

Mansfield, Edwin and Anthony Romeo (1980), Technology Transfer to Overseas Subsidiary by US-based Firms, Quarterly Journal of Economics, Vol. 95, No. 4, pp. 737-750.

Markusen, James (2002), Multinational Firms and the Theory of International Trade, Cambridge, MA: MIT Press.

Markusen, James and Anthony Venables (1999), Foreign Direct Investment as a Catalyst for Industrial Development, European Economic Review, Vol. 43, No. 2, pp. 335-356. 
Pica, Giovanni and José Rodríguez Mora (2005), FDI, Allocation of Talents and Differences in Regulation, Economics Department, University of Salerno, mimeo.

PRS Group (2005), About ICRG: The Political Risk Rating, Internet Posting: http://www.icrgonline.com/page.aspx?page=icrgmethods.

Ram, Rati and Kevin Honglin Zhang (2002), Foreign Direct Investment and Economic Growth: Evidence from Cross-Country Data for the 1990s, Economic Development and Cultural Change, Vol. 51, No. 1, pp. 205-214.

Rodríguez-Clare, Andrés (1996), Multinationals, Linkages, and Economic Development, American Economic Review, Vol. 86, No. 4, pp. 851-873.

Rodrik, Dani, Arvind Subramanian and Francesco Trebbi (2004), Institutions Rule: The Primacy of Institutions Over Geography and Integration in Economic Development, Journal of Economic Growth, Vol. 9, No. 2, pp. 131-165.

UNCTAD (1999), World Investment Report: Infrastructure for Development, New York and Geneva: United Nations.

UNCTAD (2005), Foreign Direct Investment Database (online), Internet Posting: http://www.unctad.org/Templates/Page.asp?intItemID=1923\&lang=1.

Wheeler, David and Ashoka Mody (1992) International Investment Location Decisions: The Case of US Firms, Journal of International Economics, Vol. 33, No. 1/2, pp. 57-76.

World Bank (2004), Doing Business in 2004: Understanding Regulation, World Bank and Oxford University Press: Washington, DC.

World Bank (2005a), World Development Indicators, Data on CD-ROM, World Bank: Washington, DC.

World Bank (2005b), Global Development Network Growth Database, Internet Posting: http://www.worldbank.org/research/growth/GDNdata.htm.

World Economic Forum (2005), Global Competitiveness Report 2004-2005, Houndmills, Basingstoke, Hampshire: Palgrave Macmillan. 


\section{Appendix A: Data Sources for all Variables}

\begin{tabular}{|c|c|}
\hline Variable & Source \\
\hline Real growth of Gross Domestic Product per capita in percent & World Bank (2005a) \\
\hline Gross Domestic Product per capita in international US dollars (PPP) & World Bank (2005a) \\
\hline Foreign direct investment, net inflows in percent of GDP & UNCTAD (2005) \\
\hline $\begin{array}{l}\text { Composite regulation index for business regulations, labor market regulations, } \\
\text { contract regulations, creditor rights and insolvency regulations, January } 2003\end{array}$ & World Bank (2004) \\
\hline \multicolumn{2}{|l|}{$\begin{array}{l}\text { Composite regulation dummy for the } 20 / 30 / 40 / 50 \text { percent most regulated } \\
\text { countries in the sample, } 0 \text { and } 1 \text {, January } 2003\end{array}$} \\
\hline Rule of law, 0-6 scale & PRS Group (2005) \\
\hline Change in consumer prices (CPI), computed as ln (1+CPI average inflation) & World Bank (2005a) \\
\hline Population growth in percent & World Bank (2005a) \\
\hline Government consumption divided by Gross Domestic Product & World Bank (2005a) \\
\hline $\begin{array}{l}\text { Black market premium (BMP) for foreign currency (US dollar) in percent, } \\
\text { calculated as } \ln (1+\mathrm{BMP})\end{array}$ & World Bank (2005b) \\
\hline Total imports and exports divided by Gross Domestic Product & World Bank (2005a) \\
\hline Distance from the equator, measured as absolute value of latitude of capital city & World Bank (2005b) \\
\hline Dummy for landlocked countries, 0 and 1 & World Bank (2005b) \\
\hline Legal origin dummies for British and French law, 0 and 1 & World Bank (2004) \\
\hline
\end{tabular}

\section{Appendix B: Descriptive Statistics of the Main Variables}

\begin{tabular}{lcccrr}
\hline Variable & Observations & Mean & $\begin{array}{c}\text { Standard } \\
\text { Deviation }\end{array}$ & Minimum & Maximum \\
\hline GDP per capita growth, current period & 89 & 3.02 & 1.78 & -2.57 & 8.91 \\
$\begin{array}{l}\text { GDP per capita growth, previous period } \\
\text { FDI inflows, \% of GDP, current period }\end{array}$ & 89 & 3.38 & 2.33 & -3.33 & 10.00 \\
$\begin{array}{l}\text { Change over previous period in average } \\
\text { FDI inflows }\end{array}$ & 89 & 2.82 & 2.34 & 0.06 & 13.47 \\
$\begin{array}{l}\text { Regulation index } \\
\text { Change over previous period in average }\end{array}$ & 89 & -2.10 & 0.85 & -4.24 & -0.42 \\
$\begin{array}{l}\text { rule of law } \\
\text { Change over previous period in average } \\
\text { inflation rate }\end{array}$ & 89 & 0.70 & 1.05 & -1.70 & 3.32 \\
$\begin{array}{l}\text { Change over previous period in average } \\
\text { population growth }\end{array}$ & 89 & -0.19 & 0.60 & -3.25 & 1.14 \\
$\begin{array}{l}\text { Change over previous period in average } \\
\text { government consumption }\end{array}$ & 89 & -0.74 & 3.48 & -15.02 & 10.08 \\
$\begin{array}{l}\text { Change over previous period in average } \\
\text { black market premium }\end{array}$ & 82 & -0.27 & 0.64 & -4.37 & 0.43 \\
$\begin{array}{l}\text { Change over previous period in average } \\
\text { trade }\end{array}$ & 89 & 0.18 & 0.20 & -0.18 & 0.77 \\
\hline
\end{tabular}

Note: Current and previous period refer to the periods 1994-2003 and 1984-1993, respectively. 


\section{Appendix C: Country Sample}

Albania, Algeria, Argentina, Australia, Austria, Bangladesh, Bolivia, Botswana, Brazil, Bulgaria, Burkina Faso, Cameroon, Canada, Chile, China, Colombia, Democratic Republic of Congo, Republic of Congo, Costa Rica, Cote d’Ivoire, Denmark, Dominican Republic, Ecuador, Egypt, El Salvador, Ethiopia, Finland, France, Germany, Ghana, Greece, Guatemala, Haiti, Honduras, Hungary, India, Indonesia, Iran, Ireland, Israel, Italy, Jamaica, Japan, Jordan, Kenya, Republic of Korea, Madagascar, Malawi, Malaysia, Mali, Mexico, Mongolia, Morocco, Mozambique, Namibia, Netherlands, New Zealand, Nicaragua, Niger, Nigeria, Norway, Pakistan, Panama, Papua New Guinea, Paraguay, Peru, Philippines, Portugal, Saudi Arabia, Senegal, Sierra Leone, Singapore, Slovak Republic, South Africa, Spain, Sri Lanka, Sweden, Switzerland, Syrian Arab Republic, Thailand, Togo, Tunisia, Turkey, Uganda, United Kingdom, United States, Uruguay, Venezuela, Zambia

Note: Countries highlighted in italics belong to the group of the 20 percent most regulated countries. 